\title{
PERAN PENDIDIKAN POLITIK BAGI KEHIDUPAN DI MASYARAKAT
}

\author{
Rahimah \\ 2010128220022@mhs.ulm.ac.id \\ Program Studi Pendidikan Ilmu Pengetahuan Sosial \\ Fakultas Keguruan dan Ilmu Pendidikan \\ Universitas Lambung Mangkurat
}

Banjarmasin

\begin{abstract}
Abstrak
Pendidikan politik ini dalam penulisan ini bertujuan agar masyarakatnya mampu secara sadar dalam melaksanakan aktivitas pada dunia perpolitikan secara ideal dalam menjalankannya sistem politik. Pada generasi muda sendiri pendidikan politik ini bisa membentuk karakter kepemimpinan bagi dirinya. Di samping itu, pendidikan politik ini kegiatan yang terus saja berkembang dan terus berlanjut. Karena dengan pendidikan politik ini kan membentuk kesadaran dan kepribadian bagi politik itu sendiri dan partisipasi bagi masyarakat dalam dunia perpolitikan. Pada penulisan ini menggunakan metode yang di mana materinya diperoleh dari jurnal dan buku lainnya yang relevan. Bahan yang sudah dikumpulkan lalu dipilah dan dipilih kerelevanannya dan kebenarannya. Setelah itu, dibuatlah serangkaian penulisan secara fakta dan dibentuklah dalam sebuah penulisan artikel.
\end{abstract}

\section{Kata kunci: pendidikan politik, kehidupan dan masyarakat PENDAHULUAN}

Pendidikan adalah sebuah bentuk usaha yang dijalankan atau dilakukan dalam rangka mengubah perilaku seseorang baik secara sadar maupun tidak. Adapun pengertian ilmu politik adalah ilmu yang mempelajari tentang suatu kehidupan dalam masyarakat di mana hal tersebut menyangkut dari sebuah kekuasaan. Secara ringkasnya politik ini merupakan bentuk dari segala sesuatu yang menyangkut akan hal kekuasaan, proses dari pemerintahan, pemerintahan serta bentuk dari organisasinya dan berkenaan dengan tujuan akan hal tersebut. Pendidikan politik adalah upaya untuk memberikan pemahaman ataupun pengetahuan dalam menjalankan sistem pemerintahan yang sehat dalam berkuasa. Tentunya pendidikan politik ini memiliki manfaat dalam kehidupan bermasyarakat yang 
dimana akan melatih peserta didik sebagai anggota masyarakat yang baik yang mampu berpartisipasi dalam politik. Pendidikan politik juga dapat menanamkan sebuah nilai politik yang baik untuk siswa. Dengan hal demikian maka peserta didik dapat menjadi masyarakat yang paham betul akan dunia perpolitikan yang mampu melakukannya dengan baik agar terwujudnya politik yang sesuai dengan bangsa Indonesia ini dan tidak salah dalam penggunaan kekuasaan.

Pada umumnya masyarakat tidak mengerti dan paham betul akan suatu hak dan kewajibannya sebagai warga negara. Karena mereka kebanyakannya hanya hidup sesuai dengan kepentingannya dan tidak terlalu peduli dengan hak serta kewajiban sebagaimana warga negara dan masyarakat yang baik. Demikian halnya kejadian karena kurangnya pemahaman mereka akan pendidikan politik terhadap rakyat. Padahal seharusnya dengan adanya pendidikan politik ini masyarakat akan paham. Pendidikan politik ini bertujuan agar mereka terbina dan dapat mengembangkan pengetahuan dalam kehidupan politik yang baik. Peran penting masyarakat menjadi suatu alasan dalam menyelenggarakan pendidikan politik ini. Karena dalam kehidupan berbangsa ini masyarakatlah yang berpartisipasi yang dimana dalam penggunaan hak serta kewajiban warga negara. Terkhususnya bagi generasi muda pendidikan politik dapat membentuk karakter kepemimpinan.

\section{METODE}

Pada penulisan ini menggunakan metode yang di mana materinya diperoleh dari jurnal dan buku lainnya yang relevan. Bahan yang sudah dikumpulkan lalu di pilah dan dipilih ke relevannya dan kebenarannya. Setelah itu, dibuatlah serangkaian penulisan secara fakta dan dibentuklah dalam sebuah penulisan artikel.

\section{PEMBAHASAN}

\section{A. Pengertian Pendidikan Politik}

Pada KBBI (1991) pendidikan ini merupakan sebuah proses yang mengalami perubahan dari segi tingkah laku dan sikap seseorang yang dilakukan dalam usaha yang sadar melalui proses pembelajaran dan pelatihan. Pendidikan ini merupakan usaha sadar yang dimana dilakukan oleh seseorang untuk mengubah tingkah laku dan sikap seseorang tersebut ke arah yang positif dari proses pembelajaran. Fungsi dari pendidikan ini sendiri agar menjadi 
manusia yang utuh dan memiliki kematangan dalam kedewasaannya. Pendidikan ini juga berperan untuk menjadi masyarakat yang baik dalam hidupnya sebagai warga negara.

Dalam jurnal Nasiwan sendiri Alfiyan menyebutkan bahwa pendidikan politik ini adalah usaha yang tersusun dan sadar terhadap masyarakatnya. Pendidikan politik ini berperan untuk masyarakatnya lebih mengenal nilai-nilai yang terdapat dalam suatu sistem politik yang baik. Pendidikan politik dapat menanamkan nilai politik yang dilaksanakan secara menyengaja, bersifat formal ataupun informal, terencana, serta memiliki kesadaran akan hak dan kewajiban serta mampu bertanggung jawab. Filosofi pendidikan mengatakan bahwa belajar ini proses yang begitu panjang dalam hidup. Jadi pendidikan politik ini perlunya dilakukan dengan bersinambung agar dapat meningkatkan pemahaman terhadap politik yang dimana terus saja berkembang. Hal demikian karena semakin berkembangnya juga permasalahan politik yang kompleks. Pada pendidikan politik ini tentunya melibatkan semua golongan muda maupun yang tua. Pendidikan politik ini harus dipelajari sejak dini. Karena lingkungan keluargalah yang pertama kali dalam seorang anak bersosialisasi. Keluarga akan membentuk karakter dan sikap sosial pada diri seorang anak yang pertama kali. Media masa juga berperan penting dalam pendidikan politik. Hal demikian karena mengingat penyaluran dari pendidikan politik ini.

\section{B. Fungsi dan Tujuan Pendidikan Politik}

Pendidikan politik ini penting untuk dipelajari karena dengan pendidikan politik ini diharapkan agar menjadi suatu ciri khas yang bersumber pada aspirasi yang ditemukan dari bangsa Indonesia itu sendiri secara nasional dan tercapainya sebuah tujuan yang direncanakan. Politik merupakan sebuah kegiatan yang dilakukan dengan menggunakan kekuasaan untuk menjalankan sebuah peraturan dan menjalankan keputusan yang sah yang dilakukan oleh pemerintah. Oleh sebab itu, perlunya penegakan sosial dalam menjalankan sebuah tata tertib. Tentunya kita ikut serta dalam menjalankan aktivitas politik ini dalam menentukan sebuah keputusan dan peraturan yang ada di masyarakat. Pendidikan dan politik merupakan hal yang saling berpengaruh.

Adapun tujuan dari pendidikan politik ini adalah yang dimana dengan adanya pendidikan politik maka memberikan harapan penuh pada setiap diri individu lebih mengenal dan paham betul akan nilai yang baik dalam sistem perpolitikan yang dimana 
dalam penerapannya. Selain itu juga pendidikan politik ini mampu menjadikan seseorang dalam mengemban tanggung jawab walaupun adanya perubahan sikap partisipasi dalam dunia perpolitikan. Fungsi dari pendidikan politik itu sendiri agar dapat meningkatkan pemahaman dan pengetahuan agar mereka dapat berpartisipasi dengan baik dalam berpolitik. Tentunya masyarakat harus aktif dalam berpolitik karena memiliki pengaruh yang besar. Masyarakat harus ikut dalam pengawasan politik agar terlaksananya politik yang ideal. Dengan itu betapa pentingnya pendidikan politik ini. Pendidikan politik ini pada intinya adalah suatu pemahaman akan dunia politik beserta aspeknya pada suatu masalah. Karena kehidupan ini banyak dimensi konfliknya. Artinya dengan berbuat politik akan berpengaruh dan ikut ambil dalam keputusan di tengah konflik yang ada pada perpolitikan.

Tujuan dari pendidikan politik untuk rakyat Indonesia sendiri, yaitu:

a. Paham akan hal situasi politik-sosial yang penuh dari konflik

b. Dapat memperjuangkan kepentingan bersama dan ideologi agar sejahteranya kehidupan

c. Berani dalam bertindak tegas untuk membangun situasi yang damai

d. Membangun kesadaran dalam dunia politik yang ideal dan sadar berkenaan hak serta juga kewajiban sebagai anggota masyarakat dan negara yang baik.

Karakteristik kepribadian Indonesia lewat pendidikan politik, yaitu:

a. Sadar untuk menaati hukum dan UUD 1945

b. Sadar hak serta kewajiban dan rasa tanggung jawab demi kebermanfaatan bangsa Indonesia

c. Aktif dalam berpartisipasi dalam pembangunan politik yang ideal

d. Bersinambung dalam menjaga persatuan dan kesatuan bangsa

e. Selaras dalam menjalankan kehidupan lingkungan manusia dan lingkungan alam

Pendidikan politik ini tidak hanya terarah untuk perubahan sikap pada dunia politik saja. Namun juga mengarahkan kedalam pembaharuan bentuk struktur politik dan juga lembaga masyarakatnya.

\section{Peran dari Pendidikan Politik bagi Masyarakat}

Pendidikan politik ini Seharusnya bisa berkembang dalam kebebasan dan di tengah masyarakat karena sebagai gerakan pro dan kontra. Seharusnya pendidikan politik ini 
bertujuan agar dalam mendobrak kepincangan yang ada di masyarakat yang dimana kepanjangan tersebut menimbulkan kesengsaraan pada rakyat dan pengaruh tingkat demokrasi. Sejarah singkatnya pendidikan politik ini bertujuan agar meningkatkan sikap demokrasi dari masyarakat Indonesia itu sendiri. Masyarakat harus maksimal yang berkenaan dengan hak mereka dalam berapresiasi menyampaikan suatu saran dan berpendapat serta bertanggung jawab apa yang mereka lakukan dalam kehidupan politik. Pendidikan politik ini merupakan sebuah gaya belajar dan latihan dalam sistem matikan dari kegiatan sosial sertavjuga membangun atas kebijakan antar sesama manusia di suatu wilayah Negara. diketahui sebagai upaya belajar karena dengan pendidikan politik ini perlulah berkesinambungan dalam melakukan pelaksanaannya agar masyarakat Terus dapat meningkatkan atas pemahamannya terhadap dunia politik yang di mana selalu mengalami perkembangan.

Adapun kebajikan kebijakan yang dimaksud adalah berkenaan dengan bersikap baik, jujur serta toleran terhadap bangsa kita sendiri dan pengembangan sportivitas. pendidikan politik ini identik dengan pembentukan akan hal suatu hati nurani dalam politik yang di mana secara implisitnya memuat akan rasa tanggung jawab terhadap sesama manusia. Pada demokrasi sendiri rakyat diberikan sebuah kesempatan dalam melakukan pilihan secara sendiri yang di mana menguntungkan untuk dirinya sebagai pemenuhan kebutuhan hidupnya. Dengan mendapatkan pendidikan politik ini rakyat diharapkan bisa menjadi kreatif, mandiri, kritis dan partisipasi atas diberikannya kesempatan dalam melakukan demokrasi. Dengan adanya pendidikan politik ini dimana dapat mendorong seseorang untuk melakukan sebuah perbaikan dan meningkatkan akan jaringan-jaringan politik dan kemasyarakatan menganalisis serta membahas tentang konflik aktual dengan kemampuan yang dimiliki rakyat Indonesia sendiri. Dengan hal tersebut orang akan sadar akan hak serta kewajiban sebagai warga Indonesia yang baik dalam mengatur kemasyarakatan, negara dan bangsa. Politik ini bukan monopoli jadi seorang pemimpin ataupun kelompokkelompok istimewa saja namun politik ini adalah milik bersama bagi setiap warga negaranya. Oleh sebab itu dengan pendidikan politik ini tidak hanya sebatas memahami tentang peristiwa politik serta konflik namun justru lebih menekankan kepada pelaksanaan 
politik yang dilakukan secara ideal dan benar dan benar sesuai dengan asas demokrasi. Di pendidikan ini banyak membalaskan konflik yang aktual.

Dengan adanya pendidikan ini akan memperoleh kemampuan dari rakyat dalam menganalisis tentang berbagai konflik serta dapat memecahkan dengan cara jadi rakyat itu sendiri bukan karena atas tekanan yang di atas. Apabila seseorang menyadari akan hak dan kewajibannya sebagai warga negara yang baik untuk mengatur masyarakat sekitar, negara dan pemerintahan. Politik merupakan milik bersama bukan merupakan milik dari golongan ataupun berduit lainnya. Akan tetapi politik ini adalah milik bersama bagi setiap warga negara untuk dimanfaatkan dan dipakai dalam mewujudkan keadilan sosial dan kesejahteraan bersama.

Arah dari pendidikan politik agar mengarah kepada transparansi dan keterbukaan serta kebebasan. pandangan dari kehidupan terbuka dapat memperlihatkan kebebasan manusia dalam merealisasikan dirinya sendiri yang mana berkaitan dengan relasi persamaannya dengan masyarakat sekitar. Karena demokratisasi, kebebasan personal, individualisme dan orde sosial yang maju itu saling berkaitan tidak terpisahkan. Oleh sebab itu, pernyataan dari pendidikan politik ini bahwa penentu dari masyarakat itu apakah betul maju dan bisa berkembang atau malah sebaliknya. Masyarakat dapat menjadi wujud untuk dirinya sendiri yang dimana bebas akan otonom yang mempunyai atau memiliki kemampuan serta wewenang dalam menetapkan berbagai ketetapan sosial, kultural dan politik. Pada zaman sekarang pendidikan politik mempunyai tujuan pokok yaitu agar rakyatnya dapat berpartisipasi dalam dunia politik, ke terpisahkan dalam konflik umum terbuka, ikut serta dalam menentukan kebijakan umum.

Pendidikan politik dapat menanamkan norma dan juga nilai yang berdasarkan landasan dan motivasi bangsa Indonesia juga menjadikan nilai dasar dalam pembinaan mengembangkan diri dalam kehidupan berbangsa dan bernegara. Dengan ini sangat diharapkan masyarakat sejak dini dapat memahami serta dapat menghadapi ancaman dari ideologi yang tidak sesuai dengan dasar negara yaitu Pancasila. Kewajiban dari pendidikan politik ini agar menjadi penerang dalam hal pembangunan yang mana bisa saja dimanipulasi oleh golongan atau kekuasaan yang salah. 


\section{KESIMPULAN}

Pendidikan politik ini berupaya agar sadarnya masyarakat yang berkenaan dengan dunia perpolitikan terutama hal dalam penggunaan kekuasaan serta tanggung jawabnya. Pendidikan politik ini berperan untuk masyarakatnya lebih mengenal akan sebuah nilai pada suatu sistem politik yang baik. Pendidikan politik dapat menanamkan nilai dari politik yang dilaksanakan secara menyengaja, bersifat formal ataupun informal, terencana, serta memiliki rasa sadar akan hak juga kewajiban serta mampu bertanggung jawab. Pendidikan politik ini penting untuk dipelajari karena dengan pendidikan politik ini diharapkan agar menjadi suatu ciri khas yang berasal pada aspirasi yang ditemui dari bangsa Indonesia itu sendiri secara nasional dan tercapainya sebuah tujuan yang direncanakan. Adapun tujuan dari pendidikan politik ini adalah yang dimana dengan adanya pendidikan politik maka memberikan harapan penuh pada setiap diri individu lebih mengenal dan paham betul akan

nilai yang baik dalam sistem perpolitikan yang dimana dalam penerapannya. Selain itu juga pendidikan politik ini mampu menjadikan seseorang dalam mengemban tanggung jawab walaupun adanya perubahan sikap partisipasi dalam dunia perpolitikan. Arah dari pendidikan politik agar mengarah kepada transparansi dan keterbukaan serta kebebasan. pandangan dari kehidupan terbuka dapat memperlihatkan kebebasan manusia dalam merealisasikan dirinya sendiri yang mana berkaitan dengan relasi persamaannya dengan masyarakat sekitar.

\section{REFERENSI}

Bashori, K. (2018). Pendidikan politik di era disrupsi. Sukma: Jurnal Pendidikan, 2(2), 287-310.

Elisabeth, S. (2016). Peranan Partai Politik Dalam Memberikan Pendidikan Politik yang Berkarakter Terhadap Masyarakat. Jurnal Ilmiah Research Sains, 2(1).

Kartono, K. (1996). Pendidikan Politik. Bandung: Mandar Maju.

Kharisma, D. (2015). Peran Pendidikan Politik Terhadap Partisipasi Politik Pemilih Muda. Politico: Jurnal Ilmu Politik, 1(7), 1144. 
Nadir, N., \& Wardani, W. Y. (2019). Membangun Pneididkan Politik Dalam Fatsun Demokrasi Pancasila Dan Deliberative. The Journal of Siciety and Media, 3(1), 126-141.

Putra, M. H. (2019). Character Education Through The Civilization Nations Children. The Kalimantan Social Studies, 1(1), 12-17.

Sarnoto, A. Z. (2013). Konsepsi politik pendidikan di Indonesia. Educhild: Pendidikan dan Sosial, 1(1), 30-40. 